\title{
Famennian carbonate microfacies from the Preslavtsi-2 well (Moesian Platform, north-eastern Bulgaria)
}

\author{
Polina Andreeva \\ Geological Institute, Bulgarian Academy of Sciences, Acad. G. Bonchev Str., Bl. 24, 1113 Sofia, Bulgaria; e-mail: poly_a@abv.bg \\ (Accepted in revised form: June 2019)
}

\begin{abstract}
The most representative subsurface section of the Famennian carbonate succession from the Moesian Platform in Bulgaria occurs in the R-2 Preslavtsi well. Nine microfacies types (MFTs 1-9) have been distinguished and described in the intraclastic and peloidal limestone unit and the organogenic limestone unit. They are grouped in four microfacies associations: 1) protected shallow subtidal (lagoon) (MFT 1, bioclasticpeloidal packstone/grainstone; and MFT 2, oncoidal wackestone); 2) wave-dominated shallow subtidal (MFT 3, intraclastic-peloidal grainstone and rudstone; MFT 4, oncoidal rudstone; MFT 5, peloidal-bioclastic packstone and grainstone); 3) reef (MFT 6, solenoporacean-calcimicrobial-stromatoporoid boundstone; MFT 7, crinoid-stromatoporoid floatstone); and 4) open-marine (MFT 8, bioclastic wackestone/packstone with intraclasts and peloids; and MFT 9, bioclastic wackestone and packstone). The carbonate deposits are interpreted as formed in various shallow- to open-marine environments at or above the fair-weather wave base (MFTs 1-7) and below it (MFTs 8 and 9). Most of the described microfacies are comparable with Wilson's (1975) Standard Microfacies Types.
\end{abstract}

Andreeva, P. 2019. Famennian carbonate microfacies from the Preslavtsi-2 well (Moesian Platform, north-eastern Bulgaria). Geologica Balcanica 48 (2), 13-24.

Keywords: microfacies, Famennian, Devonian, Moesian Platform, Bulgaria.

\section{INTRODUCTION}

In Bulgaria, carbonate successions of Famennian age have only been penetrated by a few deep wells in the eastern part of the Moesian Platform (Mihailova-Jovcheva, 1971; Spassov, 1971, 1983, 1987; Yanev, 1972). These deposits occur in the R-1 Chereshovo (depth interval 2843-2930 m), R-2 Preslavtsi (depth interval 1200-1810 m), R-1 Dulovo (depth interval 2058-2460 m), R-53 Belgun (depth interval 2869.40-2874 m), and R-1 Vaklino (depth interval 2319-2321.60 m) wells (Spassov, 1983; Yanev and Boncheva, 1995) (Fig. 1). The Famennian age of the rocks was proved by Mihailova-Jovcheva (1971), Spassov (1983), and Boncheva (in: Yanev and Boncheva, 1995), based on microfossil data. Yanev $(1972,1995)$ included the Famennian carbonates from the R-1 Chereshovo, R-2 Preslavtsi and R-1 Dulovo wells in two informal lithostratigraphic units: intraclastic and peloidal limestone unit and organogenic limestone unit. The petrography and dep- ositional settings of these rocks were studied also by Yanev (1972, 1974, 1995), who interpreted them as formed in shallow-marine environments.

The most representative subsurface section of the Famennian carbonate succession from the Moesian Platform in Bulgaria is drilled in the R-2 Preslavtsi well. According to Bokov and Ognyanov (1978), this Upper Devonian succession was formed in a carbonate shelf environment. More recently, Belivanova (2002) published preliminary results from a microfacies study of the Famennian rocks from the organogenic limestone unit in the same well and interpreted them as deposited in shallow-marine settings with open circulation, located below the fairweather wave base (FWWB).

The present work is focused on the Famennian successions in the Preslavtsi-2 well and aims at: 1) detailed microfacies analysis of carbonate deposits from the intraclastic and peloidal limestone unit and the organogenic limestone unit with descriptions of the main microfacies associations and 


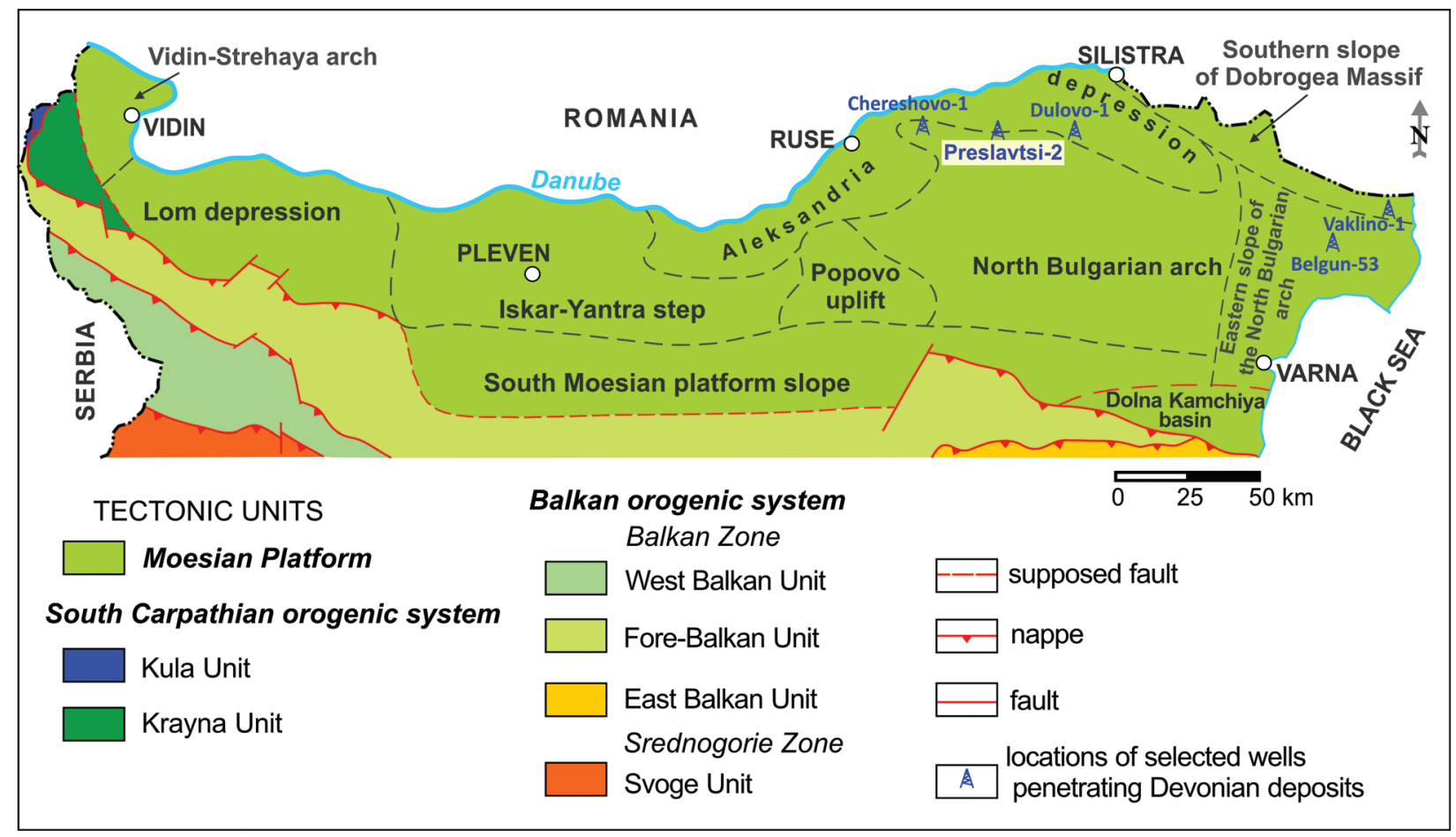

Fig. 1. Tectonic subdivision of the Moesian Platform in Bulgaria (after Dabovski and Zagorchev, 2009, modified) with shown location of the Preslavtsi-2 well and other wells penetrating Famennian rocks in the eastern part of the platform.

types; 2) interpretation of the Famennian depositional environments; and 3) comparison of the described microfacies with Wilson's (1975) Standard Microfacies Types (SMF).

\section{GEOLOGICAL SETTING AND LITHOSTRATIGRAPHY}

The Moesian Platform is a major structural unit that forms the foreland of the Alpine belt in the eastern part of the Balkan Peninsula (Bončev, 1947; Săndulescu, 1984; Dabovski and Zagorchev, 2009). In the Bulgarian part, the platform consists of several positive (arches and their slopes) and negative (depressions) structures (Vidin-Strehaya arch, Lom depression, Iskar-Yantra step, Southern platform slope, Alexandria depression, North Bulgarian arch, Southern slope of the Dobrogea Massif, Eastern slope of the North Bulgarian arch, and Dolna Kamchiya basin), which are faulted into blocks, horsts and grabens of different ranks (Dabovski and Zagorchev, 2009).

Devonian sediments in the Preslavtsi-2 well occur in the North Bulgarian arch (according to the tectonic scheme of Dabovski and Zagorchev, 2009). They were subdivided by Yanev (1972; 1995; in: Yanev and Boncheva, 1995) into several informal lithostratigraphic units (Fig. 2): carbonate-sulphate unit (Givetian), dolomite unit (Givetian), banded limestone unit (Givetian-Frasnian), intraclastic and peloidal limestone unit (Frasnian-Famennian), and organogenic limestone unit (Famennian). The conodont age determinations of Spassov (1983) and Boncheva (in: Yanev and Boncheva, 1995) are followed in this study.

The Famennian sequence in the Preslavtsi-2 well was drilled within the depth interval 1200-1810 m. Light grey to creamy grey massive bioclastic and intraclastic limestones, locally interbedded with dark grey to black argillaceous limestones, comprise the intraclastic and peloidal limestone unit (depth

Fig. 2. Lithostratigraphic subdivision of the Devonian deposits in the R-2 Preslavtsi well (Yanev, 1995; Yanev and Boncheva, 1995) and lithological log of the studied Famennian interval with distinguished microfacies types. 


\section{Preslavtsi-2}

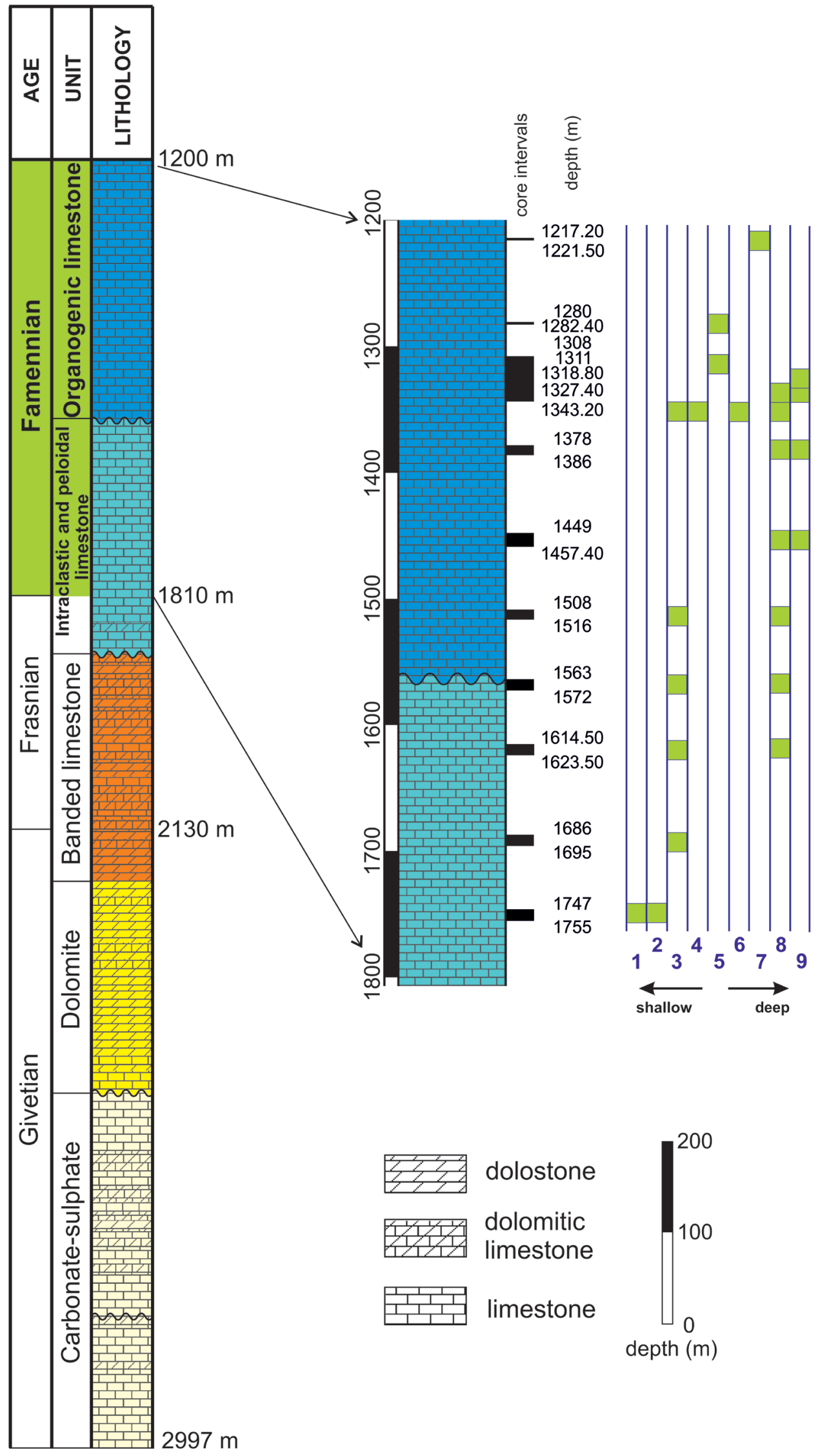


interval 1563-1894 m). The rocks contain scarce well-preserved brachiopod shells and crinoid ossicles. The organogenic limestone unit (depth interval $1220-1563 \mathrm{~m}$ ) is characterized by brownish grey to dark grey or black massive bioclastic and locally intraclastic limestones with scarce macrofossils (i.e., corals, bryozoans, brachiopods, stromatoporoids).

\section{MATERIAL AND METHODS}

Petrographic study with transmitting light-microscope was conducted on 66 thin-sections from Famennian rocks of the intraclastic and peloidal limestone unit and the organogenic limestone unit in the Preslavtsi-2 well. Microfacies types were distinguished and described, following Dunham's (1962) textural classification, expanded by Embry and Klovan (1971). The comparison charts of Baccelle and Bosellini (1962) were used to estimate the relative amount of constituent particles. The diagnostic microfacies criteria of Flügel (2004) were applied for defining the microfacies types. Most of the recognized microfacies types were compared to the Standard Microfacies Types (SMFs) of Wilson (1975), expanded by Flügel (2004).

\section{MICROFACIES ASSOCIATIONS AND TYPES}

Nine microfacies types (MFTs 1-9) have been distinguished and grouped in four microfacies as- sociations: 1) protected shallow subtidal (lagoon); 2) wave-dominated shallow subtidal; 3) reef; and 4) open-marine (Table 1).

\section{Protected shallow subtidal (lagoon) microfacies association}

This association includes two microfacies types (MFTs 1 and 2) that are interpreted as formed in protected low-energy shallow subtidal settings (lagoon). They were found only in the lowermost core interval (depth 1747-1755 m) of the intraclastic and peloidal limestone unit (Fig. 2).

\section{MFT 1 Bioclastic-peloidal packstone/grainstone}

The packstones/grainstones of MFT 1 consist of predominant peloids and variable amount of skeletal grains (Fig. 3a). The bioclasts include mainly calcispheres and ostracods, scarce palaeosiphonoclad algae, brachiopod shells and spines, as well as single crinoids, gastropods and bryozoans. The rock groundmass consists of micritic/microsparitic matrix and calcite cement. The depositional texture is locally obliterated by dolomitization.

Interpretation: The peloidal packstones/grainstones characterize a shallow-marine environment with moderate water circulation. Many skeletal grains (e.g., brachiopods, crinoids, bryozoans) are broken and were probably transported from openmarine parts of the basin during stronger storms or by currents. MFT 1 can be compared to SMF 16

Table 1

Summary of the microfacies types, microfacies associations and depositional environments from the Preslavtsi-2 well

\begin{tabular}{|c|c|c|c|}
\hline \multicolumn{2}{|c|}{ Microfacies type } & \multirow{2}{*}{$\begin{array}{l}\text { Microfacies association } \\
\begin{array}{l}\text { Protected shallow subtidal } \\
\text { (lagoon) }\end{array}\end{array}$} & \multirow{2}{*}{$\begin{array}{l}\text { Depositional environment } \\
\begin{array}{l}\text { Shallow-marine with moderate water } \\
\text { circulation }\end{array}\end{array}$} \\
\hline MFT 1 & $\begin{array}{l}\text { Bioclastic-peloidal packstone/ } \\
\text { grainstone }\end{array}$ & & \\
\hline MFT 2 & Oncoidal wackestone & $\begin{array}{l}\text { Protected shallow subtidal } \\
\text { (lagoon) }\end{array}$ & Poorly agitated shallow-marine \\
\hline MFT 3 & $\begin{array}{l}\text { Intraclastic-peloidal grainstone and } \\
\text { rudstone }\end{array}$ & $\begin{array}{l}\text { Wave-dominated shallow } \\
\text { subtidal }\end{array}$ & $\begin{array}{l}\text { High-energy shallow- marine at or above } \\
\text { FWWB }\end{array}$ \\
\hline MFT 4 & Oncoidal rudstone & $\begin{array}{l}\text { Wave-dominated shallow } \\
\text { subtidal }\end{array}$ & $\begin{array}{l}\text { High-energy shallow- marine at or above } \\
\text { FWWB }\end{array}$ \\
\hline MFT 5 & $\begin{array}{l}\text { Peloidal-bioclastic packstone and } \\
\text { grainstone }\end{array}$ & $\begin{array}{l}\text { Wave-dominated shallow } \\
\text { subtidal }\end{array}$ & $\begin{array}{l}\text { High-energy shallow- marine at or above } \\
\text { FWWB }\end{array}$ \\
\hline MFT 6 & $\begin{array}{l}\text { Solenoporacean-calcimicrobial- } \\
\text { strimatoporoid boundstone }\end{array}$ & Reef & $\begin{array}{l}\text { Shallow- marine with in-situ growth of reef } \\
\text { builders }\end{array}$ \\
\hline MFT 7 & Crinoid-stromatoporoid floatstone & Reef & $\begin{array}{l}\text { Agitated shallow-marine with reef-derived } \\
\text { bioclasts }\end{array}$ \\
\hline MFT 8 & $\begin{array}{l}\text { Bioclastic wackestone/packstone } \\
\text { with peloids and intraclasts }\end{array}$ & Open-marine & Open- marine below FWWB \\
\hline MFT 9 & $\begin{array}{l}\text { Bioclastic wackestone and } \\
\text { packstone }\end{array}$ & Open-marine & Open-marine setting below FWWB \\
\hline
\end{tabular}


(non-laminated subtype) "Non-laminated peloidal packstones and grainstones", which is typical for protected shallow-marine environments (lagoons) with moderate water circulation (Wilson, 1975; Flügel, 2004).

\section{MFT 2 Oncoidal wackestone}

This microfacies consists of oncoids, skeletal grains (crinoids, gastropods, ostracods, calcareous green algae, brachiopods), scarce peloids, and micritic/ microsparitic matrix. The oncoids have various sizes (from $0.2 \mathrm{~mm}$ to $1.8 \mathrm{~mm}$ ) and symmetrical or asymmetrical micritic cortices (Fig. 3b). Their nuclei include bioclasts and micritic intraclasts. Some skeletal grains have micritic envelopes (i.e., cortoids) and others are strongly micritized (Fig. 3c).

Interpretation: The oncoids and cortoids are interpreted as formed in a non-agitated shallowmarine environment. This is evidenced by the nonwinnowed texture and local presence of asymmetrical oncoid cortices that indicate stationary growth. The fossil association (crinoids, green algae, brachiopods) characterizes normal marine salinity. MFT 2 can be compared to SMF 22 "Oncoid floatstone or wackestone” deposited in low-energy lagoons and tidal-flat settings (Wilson, 1975; Flügel, 2004).

\section{Wave-dominated shallow subtidal microfacies association}

This microfacies association is distinguished in both of the studied units. The microfacies types (MFTs 3-5) are interpreted as deposited in high-energy shallow-marine settings (carbonate sand shoals) with normal marine salinity and constant wave action, at or above FWWB.

\section{MFT 3 Intraclastic-peloidal grainstone and rudstone}

This microfacies comprises grainstones and grainstones/rudstones with predominant intraclasts and peloids (Fig. $3 d-f$ ). The associated skeletal grains include: crinoids, broken brachiopod shells and spines, ostracods, calcispheres, calcimicrobes, echinoid spines, benthic foraminifera, calcareous red algae (solenoporacean), palaeosiphonoclad algae, and stromatoporoid bioclasts. Some of them have micrite envelopes and others are strongly micritized. The poorly to moderately sorted intraclasts derived mainly from calcimudstones and subordinately from bioclastic wackestones and bioclastic-peloidal packstones. They have various sizes (from $0.2 \mathrm{~mm}$ to $8.0 \mathrm{~mm}$ ), shapes (elongate, oval or irregular), and roundness (subrounded to well rounded). The allochems are cemented by sparry calcite or, rarely, dispersed within micritic/microsparitic matrix. The microfacies is recognized in the intraclastic and peloidal limestone unit and the organogenic limestone unit.

Interpretation: The winnowed texture and the presence of reworked intraclasts reflect an agitated shallow-marine environment at or above FWWB. Most of the peloids originated from disintegration and reworking of micritic intraclasts ("mud peloids" after Fabricius, 1966), or represent small micritized bioclasts.

\section{MFT 4 Oncoidal rudstone}

These limestones are characterized by bimodal grain-size distribution with large $(1.5-3 \mathrm{~mm})$ and small $(0.2-0.4 \mathrm{~mm})$ oncoids associated with peloids, micritic intraclasts and micritized bioclasts. The skeletal grains include: crinoids, bivalves, ostracods, calcispheres, echinoids, and brachiopods. The oncoid cortices are composed of indistinct micritic laminae (Fig. 3g, $h$ ), locally with entrapped small bioclasts (Fig. 3g). The nuclei comprise skeletal grains or micritic intraclasts. The groundmass is sparitic cement or, more rarely, micritic/microsparitic matrix. The microfacies has minor occurrence only in the organogenic limestone unit.

Interpretation: The rudstone texture, fossil assemblage and presence of micritic intraclasts indicate deposition in an agitated shallow-marine environment with normal marine salinity and intense water circulation. Most probably, this setting was located near to or above FWWB. This microfacies type can be correlated with SMF 13 "Oncoid rudstones and grainstones" that characterizes various shallow-marine settings (Wilson, 1975; Flügel, 2004).

\section{MFT 5 Peloidal-bioclastic packstone and grainstone}

This microfacies consists of packstones and grainstones containing variable amounts of peloids and bioclasts (Fig. 4a, b). Crinoids (Fig. 4a, b), benthic foraminifera (Fig. 4a) and brachiopods (Fig. 4b) are the dominant skeletal grains. Ostracods, echinoid spines, calcispheres, single gastropod shells and palaeosiphonoclad algae were also observed. Some of them are micritized and discrete borings filled with micrite were recognized (Fig. $4 b$ ). Other allochems include scarce reworked micritic intraclasts. The groundmass is sparry cement or micritic/ microsparitic matrix. Some echinoderm fragments 

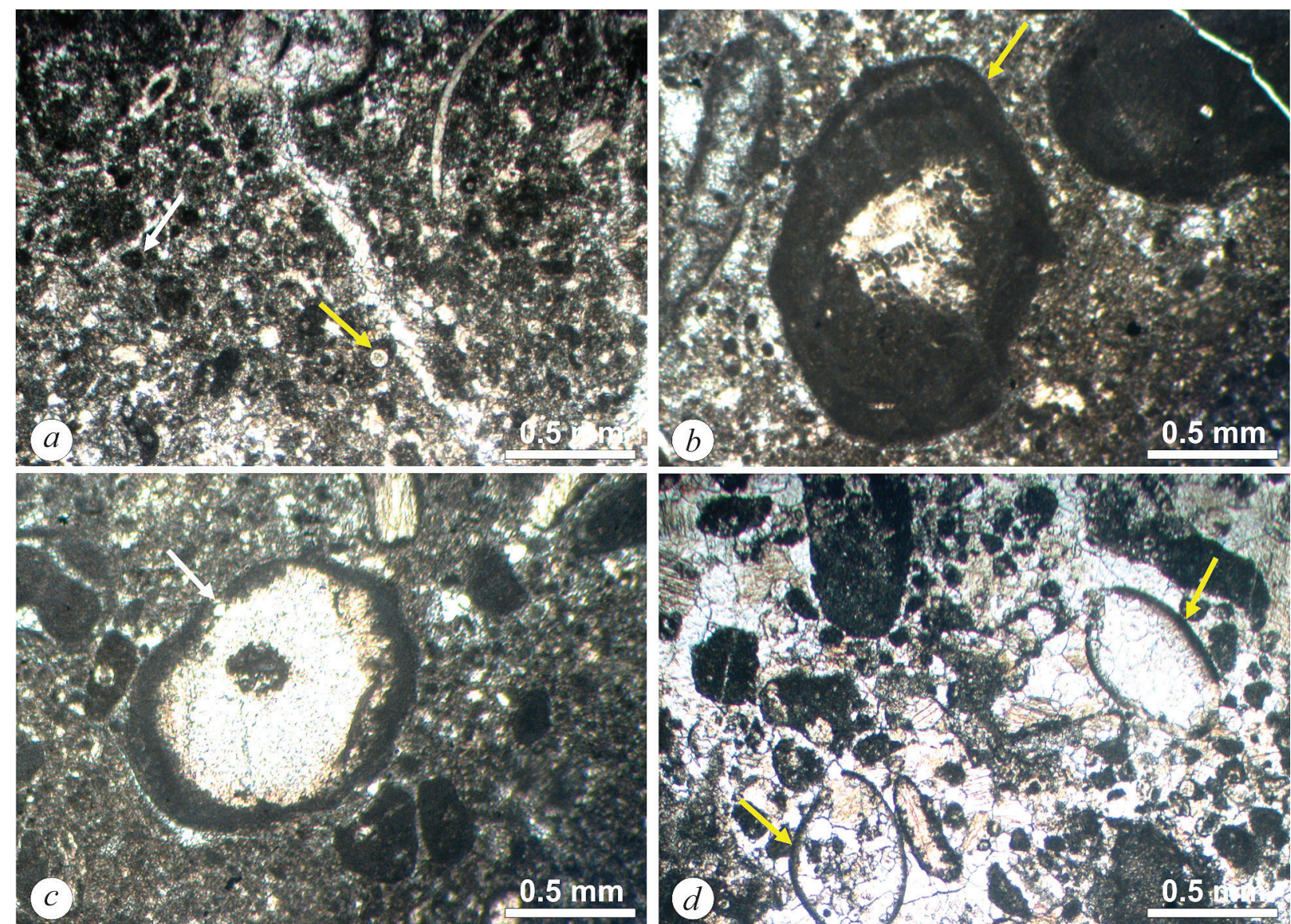

(b)

$0.5 \mathrm{~mm}$

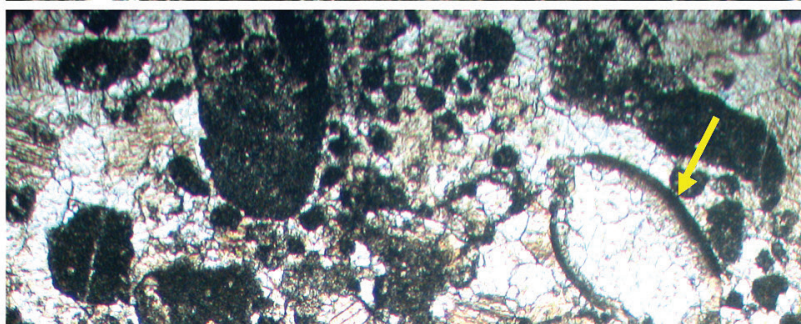

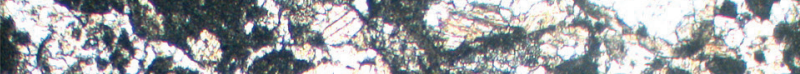

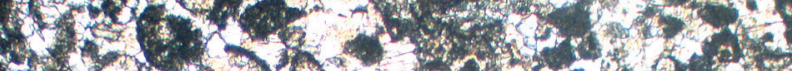

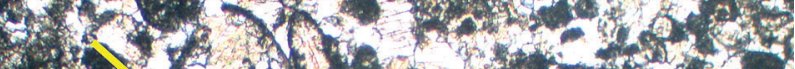

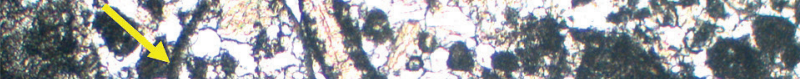

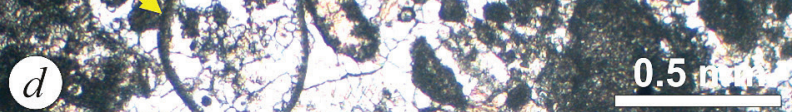

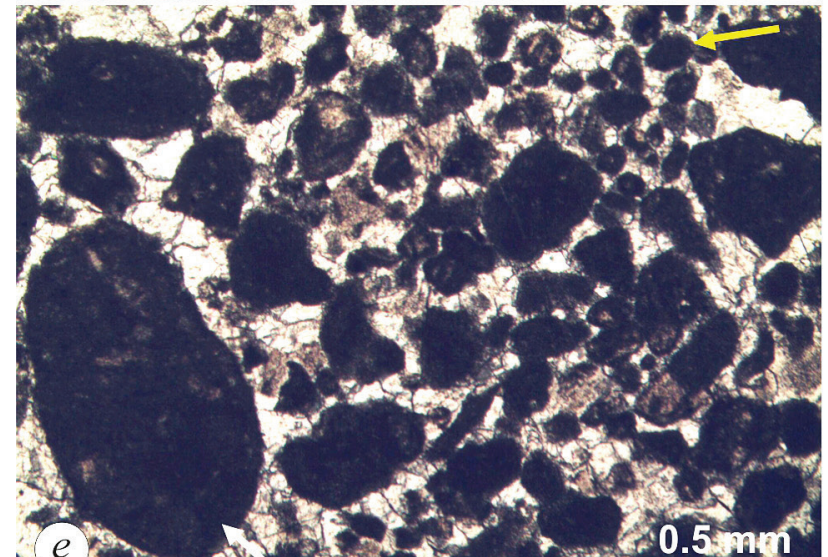

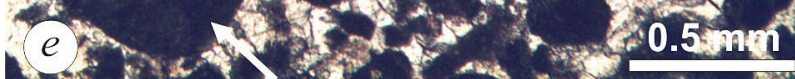
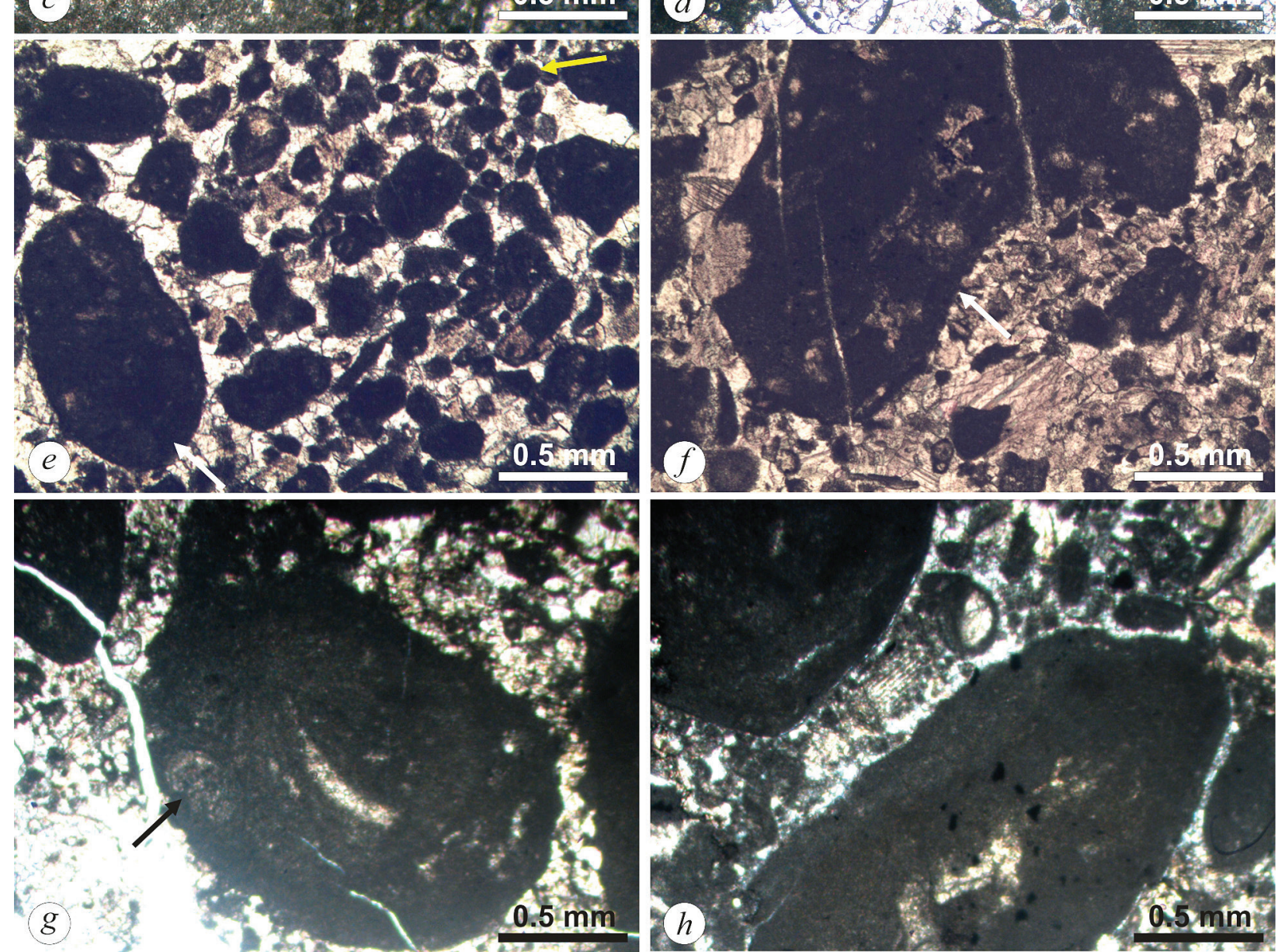
Fig. 3. a) Bioclastic-peloidal packstone/grainstone containing peloids (white arrow) and calcispheres (yellow arrow). MFT 1, intraclastic and peloidal limestone unit, core interval 1747-1755 m, depth $1748.80 \mathrm{~m}$; b) Oncoid (yellow arrow) with micritic cortex and bioclast nucleus. MFT 2, intraclastic and peloidal limestone unit, core interval 1747-1755 m, depth 1752 m; c) Crinoid bioclast converted into cortoid (white arrow). MFT 2, intraclastic and peloidal limestone unit, core interval 1747-1755 m, depth $1752 \mathrm{~m}$; d) Micritized ostracod shells (yellow arrows) in grainstone. MFT 3, organogenic limestone unit, core interval 1508-1516 m, depth $1508 \mathrm{~m}$; e) Grainstone consisting of micritic intraclasts (white arrow) and peloids (yellow arrow). MFT 3, intraclastic and peloidal limestone unit, core interval 1563-1572 m, depth $1567.20 \mathrm{~m}$; f) Large intraclast (white arrow) from bioclastic wackestone. MFT 3, intraclastic and peloidal limestone unit, core interval 1686-1695 m, depth $1689.10 \mathrm{~m} ; \mathrm{g}$ ) Oncoid with bioclast nuclei and micrite coating with entrapped small bioclast (black arrow). MFT 4, organogenic limestone unit, core interval 1327.40-1343.20 m, depth $1332.50 \mathrm{~m}$; h) Oncoidal rudstone. MFT 4, organogenic limestone unit, core interval 1327.40-1343.20 m, depth 1332.50 m. Note: all microphotographs are in plane-polarized light.

have syntaxial overgrowths. MFT 5 is found only in the upper parts of the organogenic limestone unit.

Interpretation: The grain-supported texture and presence of benthic foraminifera, calcispheres, ostracods and gastropods indicate an agitated shallowmarine setting. The common echinoderm bioclasts suggest normal marine salinity. Most likely, the carbonate deposits were formed at or above FWWB.

\section{Reef microfacies association}

This association includes organogenic build-ups (MFT 6) and deposits with reef-derived debris (MFT 7), both indicating shallow-marine environment with normal water salinity.

\section{MFT 6 Solenoporacean-calcimicrobial- stromatoporoid boundstone}

This microfacies represents boundstones consisting mainly of calcimicrobes, calcareous red algae (solenoporacean) and recrystallized or micritized stromatoporoids(?) (Fig. 4c-e). Clotted micrite and peloids are also common constituents. The skeletal grains include calcispheres, ostracods, crinoids, echinoids, micritized brachiopods and single benthic foraminifera. The microfacies shows minor occurrence only in the upper part of the organogenic limestone unit.

Interpretation: The local occurrence of the boundstones containing red algae stromatoporoids and calcimicrobes suggests their formation as patch reefs in a normal marine setting with open water circulation. MFT 6 is similar to SMF 7 "Organic boundstone", characterized by in-situ organic growth of reef builders (Wilson, 1975; Flügel, 2004).

\section{MFT 7 Crinoid-stromatoporoid floatstone}

This microfacies is composed of large (up to $1 \mathrm{~cm}$ ), commonly recrystallized bioclasts of stromatoporo- ids (Fig. 4f, g) and crinoids (Fig. 4h) in bioclastic wackestone/packstone matrix. The latter contains ostracods, calcispheres, benthic foraminifera (Fig. 5a), scarce whole gastropod shells and single echinoid spines. Peloids are also present in the matrix in variable amount. The allochems are poorly sorted. Microstylolites with opaque material are common between some bioclasts (Fig. $5 b$ ). The microfacies occurs only in the uppermost levels of the organogenic limestone unit.

Interpretation: The large stromatoporoid bioclasts indicate close proximity to a reef environment. Most probably, these skeletal grains were transported during high-energy storm events. The fossil association in the wackestone/packstone matrix (benthic foraminifera, ostracods, gastropods, calcispheres) characterizes a shallow-water marine setting. MFT 7 can be correlated with SMF 5 "Allochtonous bioclastic grainstone, rudstone, packstone and floatstone or breccias", formed in various reef settings (Wilson, 1975; Flügel, 2004).

\section{Open-marine microfacies association}

This microfacies association is characterized by carbonate microfacies deposited in marine settings with open water circulation. The open-marine association includes two microfacies (MFT 8 and MFT 9), interpreted as formed below FWWB. They are commonly observed in the intraclastic and peloidal limestone unit and the organogenic limestone unit.

\section{MFT 8 Bioclastic wackestone/packstone with peloids and intraclasts}

This microfacies contains predominant bioclasts and variable amount of peloids and micritic intraclasts. The skeletal grains are mostly crinoids, brachiopods (shells or separate spines), and echinoid spines (Fig. $5 c$ ), plus scarce foraminifera, calcitized siliceous sponge spicules, calcispheres, ostracods, gastropods, corals, and palaeosiphonoclad algae. 

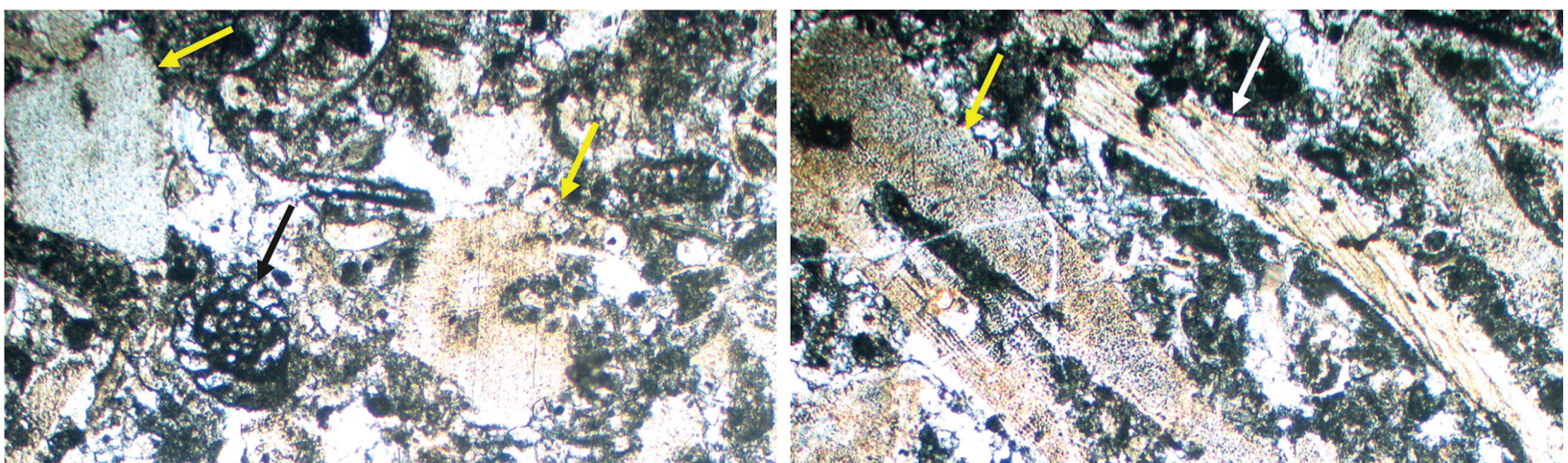

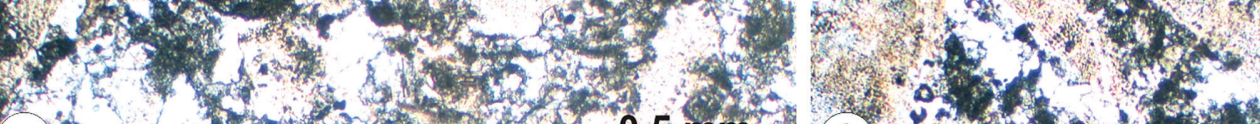

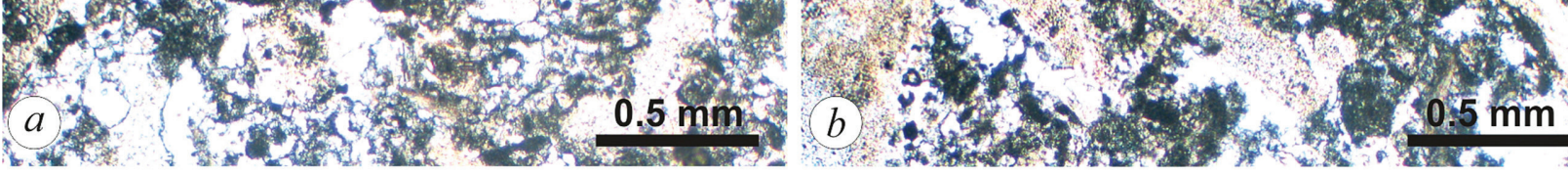

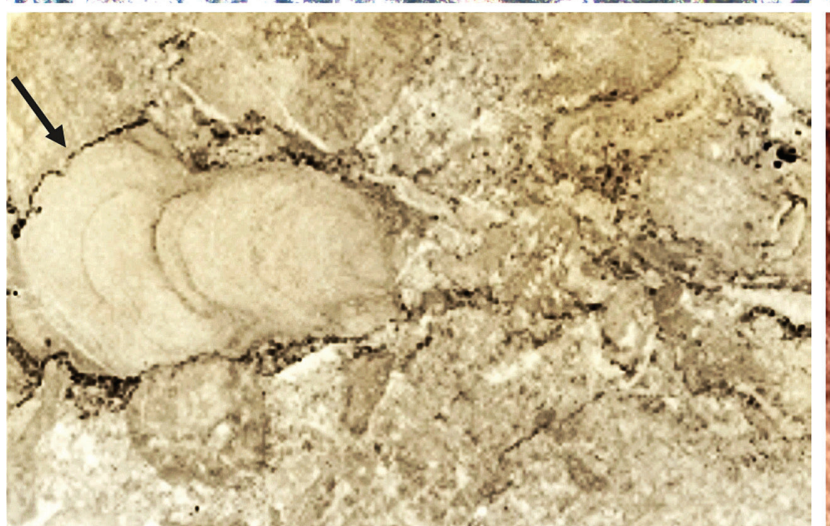

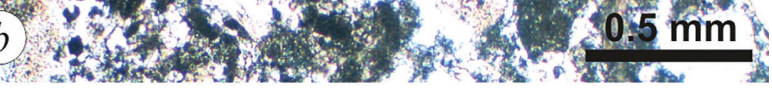
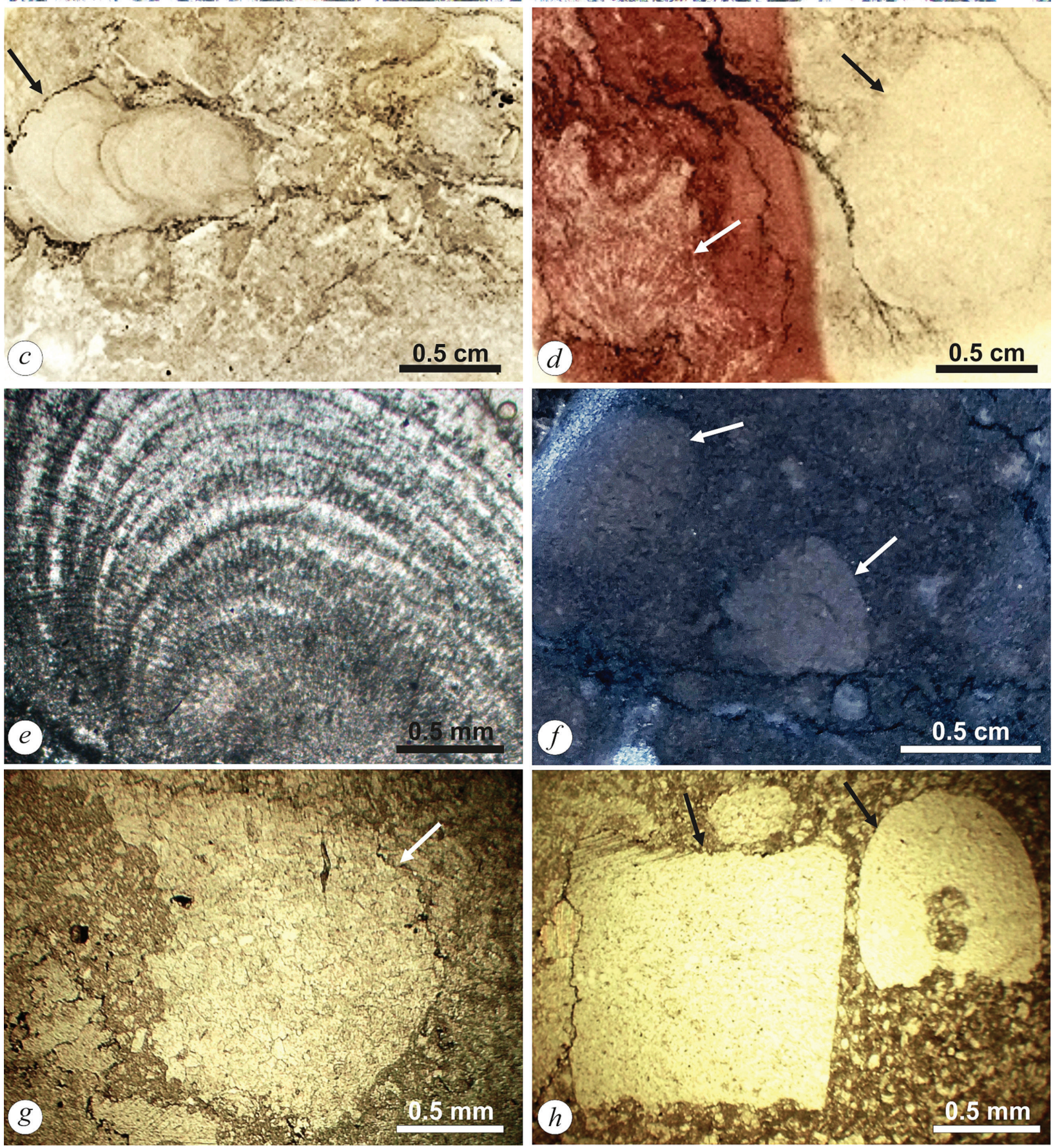
Fig. 4. a) Peloidal bioclastic grainstone containing crinoids (yellow arrows) and benthic foraminifera (black arrow). MFT 5, organogenic limestone unit, core interval 1308-1311 m, depth 1308 m; b) Large crinoid bioclast (yellow arrow) and brachiopod shell (white arrow) with micrite-filled borings. MFT 5, organogenic limestone unit, core interval 1308-1311 m, depth $1308 \mathrm{~m}$; c) Solenoporacean-calcimicrobial boundstone containing large solenoporacean remains (black arrow). MFT 6, organogenic limestone unit, core interval 1327.40-1343.20 m, depth $1332.50 \mathrm{~m}$; d) Solenoporacean-calcimicrobial boundstone with well-preserved calcimicrobes (white arrow) and recrystallized stromatoporoid(?) bioclast (black arrow). MFT 6, organogenic limestone unit, core interval 1327.40-1343.20 m, depth $1332.50 \mathrm{~m}$, stained thin-section; e) Solenoporacean red algae. MFT 6, organogenic limestone unit, core interval 1327.40-1343.20 m, depth $1332.50 \mathrm{~m}$; f) Floatstone with large stromatoporoid bioclasts (white arrows). MFT 7, organogenic limestone unit, core interval 1217.20-1221.50 m, depth $1220.40 \mathrm{~m}$, polished slab surface; g) Recrystallized stromatoporoid bioclast (white arrow). MFT 7, organogenic limestone unit, core interval 1217.20-1221.50 m, depth $1220.40 \mathrm{~m}$; h) Crinoid bioclasts (black arrows). MFT 7, organogenic limestone unit, core interval 1217.20-1221.50 m, depth 1220.40 m. Note: all microphotographs are in plane-polarized light.

Some echinoderm bioclasts display syntaxial overgrowths. Micritized fossil remains (including cortoids) are also common. The intraclasts (Fig. 5d) are characterized by elongated or rarely oval shapes. The peloids are moderately sorted. The matrix is commonly recrystallized or dolomitized.

Interpretation: The fossil assemblage, including predominant echinoderms, and the micritic matrix indicate non-agitated environment with normal marine salinity. However, occasional periods of highenergy hydrodynamic conditions are suggested by the presence of micritic intraclasts and broken skeletal remains. Some bioclasts (calcispheres, foraminifera) were probably transported from the shallower parts of the basin. Peloids are interpreted as strongly reworked micritic intraclasts or micritized small bioclasts.

\section{MFT 9 Bioclastic wackestone and packstone}

This microfacies contains poorly sorted, broken or abraded, diverse bioclasts (crinoids, bryozoans, echinoids, brachiopods, corals, calcitized siliceous sponge spicules, gastropods) and abundant unrecognizable biodetritus (Fig. 5e-h). Most of the skeletal grains are concentrated in clusters (Fig. 5h) and elsewhere display subparallel alignment. Some crinoid ossicles and brachiopod shells have borings filled with micrite. The micritic/microsparitic matrix is dark brown in colour due to higher organic and/or clay content.

Interpretation: The rich fauna assemblage characterizes an open-marine setting with normal seawater salinity. The matrix indicates low bottom hydrodynamics. However, the occurrence of small biodetritus, bioclast concentrations and subparallel arrangement of skeletal grains suggests intermittent high-energy conditions, presumably related to storm activity. The deposits of this microfacies are interpreted as formed near to or below FWWB.

\section{DISCUSSION AND CONCLUSIONS}

The Famennian deposits in the R-2 Preslavtsi well from the Moesian Platform (north-eastern Bulgaria) are interpreted as formed in various depositional environments, including protected shallow subtidal lagoons, wave-dominated carbonate sand shoals, organogenic reefs and open-marine settings below FWWB. Thus, the Upper Devonian rocks of the intraclastic and peloidal limestone unit were deposited in low- to high-energy shallow subtidal to open-marine environments. The similarity between the Famennian low-energy subtidal deposits (MFTs 1 and 2, core interval 1747-1755 m) and the underlying Frasnian lagoon succession (Andreeva, 2018) suggests a transitional sedimentary environment across the Frasnian/Famennian boundary. This lagoon setting was progressively replaced by a more agitated wave-dominated shallow subtidal environment such as carbonate sand shoals (MFT 3, core interval 1686-1695 m) located at or above FWWB. The upper part of the intraclastic and peloidal limestone unit (core interval $1614.50-1623.50 \mathrm{~m}$ ) is characterized by alternating deposits of wave-dominated shallow subtidal setting (MFT 3) and open-marine depositional environment (MFT 8).

The lowermost parts of the organogenic limestone unit is also characterized by high-energy shallow subtidal (MFT 3) and open-marine (MFT 8) depositional settings (core intervals 1563-1572 m and 1508-1516 m). Up-section, the sedimentation continued mainly in open-marine environments below FWWB (MFTs 8 and 9, core intervals 1449$1457.40 \mathrm{~m}, 1378-1386 \mathrm{~m}$ and $1318.80-1327.40 \mathrm{~m}$ ). A shallowing-upward trend is recognized in the upper part of the organogenic limestone unit (core intervals $1318.80-1327.40 \mathrm{~m}, 1308-1311 \mathrm{~m}$ and 1280-1282.40 m) where open-marine deposition (MFTs 8 and 9) was replaced by development of 

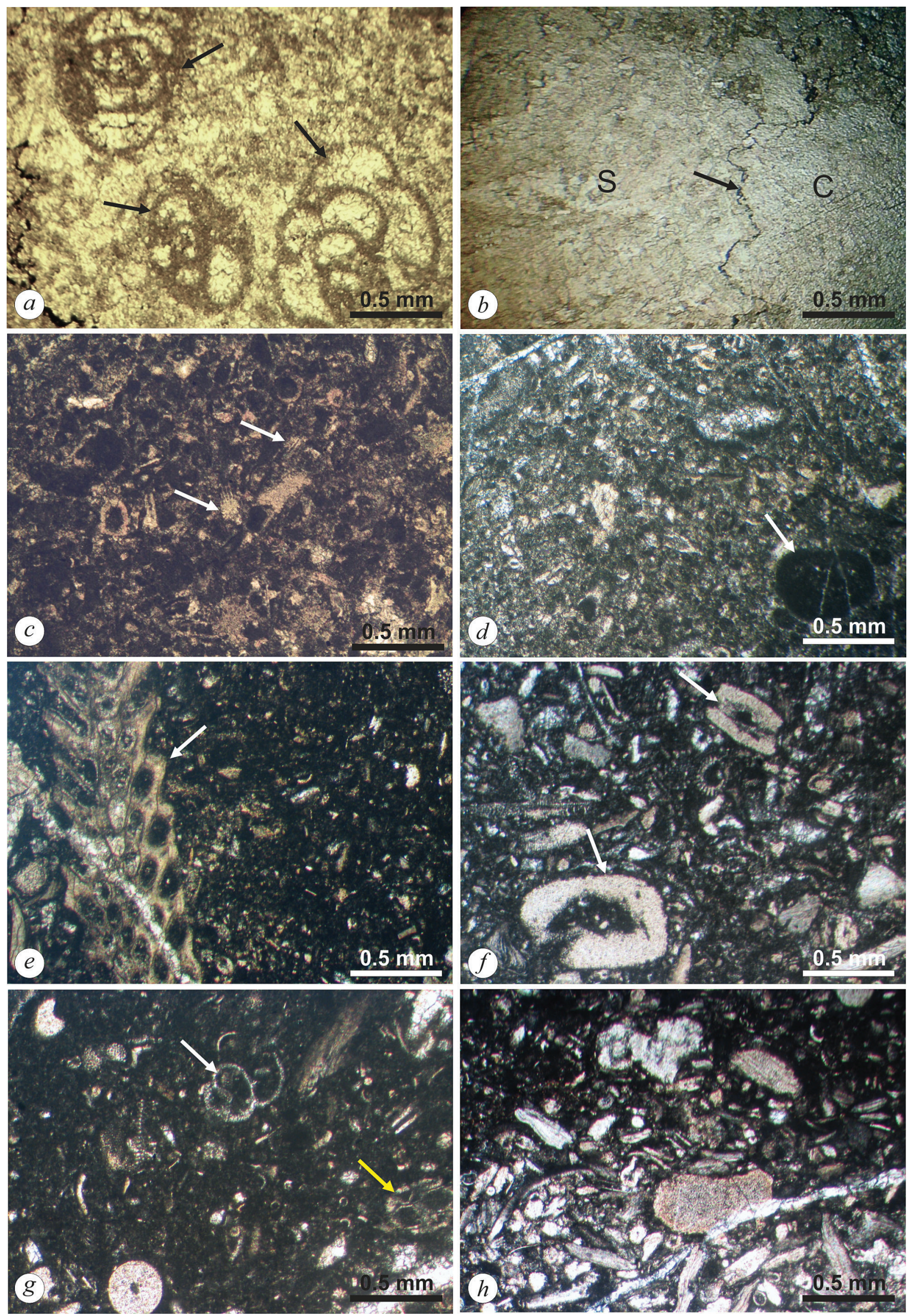
Fig. 5. a) Well-preserved benthic foraminifera (black arrows). MFT 7, organogenic limestone unit, core interval 1217.20 $1221.50 \mathrm{~m}$, depth $1220.40 \mathrm{~m}$; b) Microstylolite (black arrow) between recrystallized stromatoporoid (S) and crinoid (C) bioclast. MFT 7, organogenic limestone unit, core interval 1217.20-1221.50 m, depth $1220.40 \mathrm{~m}$; c) Bioclastic wackestone/packstone with peloids and intraclasts containing echinoid spines (white arrows). MFT 8, organogenic limestone unit, core interval 1449 $1457.40 \mathrm{~m}$, depth $1452 \mathrm{~m}$; d) Bioclastic wackestone/packstone with peloids and intraclasts (white arrow). MFT 8, organogenic limestone unit, core interval 1449-1457.40 m, depth $1452.70 \mathrm{~m}$; e) Bioclastic wackestone with well-preserved bryozoan branch (white arrow). MFT 9, organogenic limestone unit, core interval 1318.80-1327.40 m, depth 1324 m; $f$ ) Wackestone/packstone with abundant small bioclasts and crinoid ossicles (white arrows). MFT 9, organogenic limestone unit, core interval 1318.80$1327.40 \mathrm{~m}$, depth $1324 \mathrm{~m}$; g) Whole gastropod shell (white arrow) and coral bioclast (yellow arrow) in bioclastic wackestone. MFT 9, organogenic limestone unit, core interval 1311-1318.80 m, depth 1312; $h$ ) Concentrations of bioclasts. MFT 9, organogenic limestone unit, core interval 1311-1318.80 m, depth 1312. Note: all microphotographs are in plane-polarized light.

patch-reefs (MFT 6) and wave-dominated shallowmarine deposits formed above FWWB (MFTs 3, 4 and 5). At the end of the Famennian, the deposition became dominated by high-energy shallow-marine settings with reef-derived bioclasts (MFT 7, core interval 1217.20-1221.50 m).

The new data indicate that a significant change occurred in the carbonate deposition during the Famennian in the north-eastern part of the Moesian Platform in Bulgaria. The arid environments with restricted water circulation that dominated during the Givetian and the Frasnian (Yanev, 2000; Andreeva, 2018) were gradually replaced by high-energy shallow and deeper marine settings with normal water salinity and open circulation. The Famennian carbonates are characterized by a rich faunal association (brachiopods, corals, stromatoporoids, gastropods, crinoids, foraminifera, calcareous algae, ostracods, calcispheres, echinoids, bryozoans), suggesting warm and oxidized marine waters. Most probably, this change in the depositional regime was related to the northward migration of the Moesian Terrane in Northern Gondwana from the southern temperate zone during the Silurian through the southern arid zone during the Givetian and to the humid equatorial zone during the Late Carboniferous (Yanev, 2000; Yanev et al., 2005).

\section{Acknowledgements}

I am thankful to Prof. Slavcho Yanev (Geological Institute, Bulgarian Academy of Sciences) for the given opportunity to use his thin-section collection and primary documentation. Prof. Athanas Chatalov (Sofia University “St Kliment Ohridski”) and Dr Antoneta Seghedi (National Institute for Research and Development of Marine Geology and Geoecology, GeoEcoMar, Romania) are thanked for critical reviews of the manuscript. I am grateful to Drs Georgi Granchovski and Lubomir Metodiev (Geological Institute, Bulgarian Academy of Sciences) for their editorial help.

\section{REFERENCES}

Andreeva, P. 2018. Givetian-Frasnian arid palaeoenvironments from the northern Gondwana: a case study from the Moesian platform (Bulgaria). Palaeobiodiversity and Palaeoenvironments 98 (4), 549-569.

Baccelle, L., Bosellini, A. 1965. Diagrammi per la stima visiva della composizione percentuale nelle rocce sedimentaire. Annali dell'Università di Ferrara, Nuova Serie, Sezione IX, Scienze Geologiche e Paleontologiche 1, 59-62.

Belivanova, V. 2002. Microfacies of the Paleozoic carbonate rocks from Northeast Bulgaria - preliminary results. Comptes rendus de l'Académie bulgare des Sciences 55 (9), 73-77.

Bokov, P., Ognyanov, A. 1978. Facies variety in Famennian-Lower Visean deposits from Northeastern Bulgaria.
Comptes rendus de l'Académie bulgare des Sciences 31 (5), 583-586 (in Russian).

Bončev, E. 1947. Bases de la tectonique de la Bulgarie. In: Cohen, E., Dimitroff, T., Kamenoff, B. (Eds), Geologie de la Bulgarie. Annuaire de la Direction pour les recherches géologiques et minières en Bulgarie, Série A, vol. 4, 336379 (in Bulgarian).

Dabovski, H., Zagorchev, I. 2009. Introduction: Mesozoic evolution and Alpine structure. In: Zagorchev, I., Dabovski, H., Nikolov, T. (Eds), Geology of Bulgaria. Vol. II. Mesozoic geology. "Prof. M. Drinov" Academic Press, Sofia, 15-37 (in Bulgarian, with English abstract).

Dunham, R.J. 1962. Classification of carbonate rocks according to depositional texture. In: Ham, W.E. (Ed.), Classifi- 
cation of carbonate rocks. American Association of Petroleum Geologists, Memoir 1, 108-171.

Embry, A.F., Klovan, J.E. 1971. A late Devonian reef tract on northeastern Banks Island, N.W.T. Bulletin of Canadian Petroleum Geology 19, 730-781.

Fabricius, F.H. 1966. Beckensedimentation und Riffbildung an der Wende Trias/Jura in den Bayerisch-Tiroler Kalkalpen. International Sedimentary Petrographical Series 9, 1-143.

Flügel, E. 2004. Microfacies of Carbonate Rocks. Springer, Berlin, 976 pp.

Mihailova-Jovcheva, P.1971. Données microfaunistiques pour la division du Dévonien et le Carbonifère dans les trous de forages de la Bulgarie du Nord-est. Bulletin of the Geological Institute 20, 129-137 (in Bulgarian, with French abstract).

Săndulescu, M. 1984. Geotectonics of Romania. Editura Tehnică, Bucureşti, 336 pp. (in Romanian).

Spassov, H. 1971. Lithostratigraphic subdivision and correlation of Devonian sediments in the Moesian Platform. Review of the Bulgarian Geological Society 32, 221-230 (in Bulgarian).

Spassov, H. 1983. Biostratigraphy of the Devonian in North Bulgaria. I. Upper Devonian conodonts. Palaeontology, Stratigraphy and Lithology 18, 3-24 (in Bulgarian).

Spassov, H. 1987. The Devonian System in Bulgaria. In: Flügel, H.W., Sassi, F.P., Grecula, P. (Eds), Pre-Variscan and Variscan events in the Alpine-Mediterranean mountain belts. Mineralia Slovaca Monography, Alfa Bratislava, 435-444.

Wilson, J.L. 1975. Carbonate facies in geologic history. Springer-Verlag, Berlin, 473 pp.

Yanev, S. 1972. Lithologic subdivision and correlation of the Devonian and Lower Carboniferous sediments from wells in Northeastern Bulgaria. Bulletin of the Geological Institute 21, 101-124 (in Bulgarian).

Yanev, S. 1974. Facial analysis of the Devonian sediments from Northeastern Bulgaria. Bulletin of the Geological Institute 23, 107-119 (in Bulgarian).

Yanev, S. 1995. Sedimentology of the Palaeozoic Erathem in Bulgaria. DSc thesis, Geological Institute, BAS, Sofia, 552 pp. (in Bulgarian).

Yanev, S. 2000. Paleozoic terranes of the Balkan peninsula in the framework of Pangea assembly. Palaeogeography, Palaeoclimatology, Palaeoecology 161, 157-177.

Yanev, S., Boncheva, I. 1995. Contribution to the Paleozoic evolution of the recent Moesian platform. Geologica Balcanica 25 (5-6), 3-21.

Yanev, S., Lakova, I., Boncheva, I., Sachanski, V. 2005. The Moesian and Balkan Terranes in Bulgaria: Paleozoic basin development, palaeogeography and tectonic evolution. Avalonia-Moesia: Early Paleozoic orogens in the trans-European suture zone. Geologica Belgica 8, 185-192. 